\title{
Nigerian Building Professionals' Ethical Ideology and Perceived Ethical Judgement
}

John Oko Ameh, (Department of Building, University of Lagos, Nigeria)

Koleola Tunwase Odusami, (Department of Building, University of Lagos, Nigeria)

\begin{abstract}
In recent years, Nigeria is often cited in the international media in connection with corruption and other unethical practices. The professionals in the Nigerian building industry are not immune from the perceived national trend in ethical erosion. Moral philosophy or ethical ideology has been used to explain individuals' reasoning about moral issues and consequent behaviour. This study examines building industry professionals' ethical ideologies with a view to understanding their ethical behaviour in professional practice. In carrying out this investigation, building professionals in clients' organisations, contracting and consultancy organisations within the industry were asked to respond to the Ethics Position Questionnaire (EPQ) designed by Forsyth in order to determine their idealism and relativism level. Subsequently, they were classified into one of four groups, representing different ethical ideologies. The result indicates that the dominant ethical ideology of building industry professionals is situationism. The study predicts that the attitude of building industry professionals in practice, given the current socio-political and economic situation of Nigeria would possibly be unethical because of the extreme influence situational factors have on their behaviour. This finding is a bold step and necessary benchmark for resolving ethical issues within the industry and should be of interest to policy makers. It is also useful for intra professional ethical comparison.
\end{abstract}

Keywords: Professional, building industry, ethical ideology, ethical judgement, Nigeria

\section{Introduction}

Corrupt practices are found in every phase of the procurement of building projects - during planning and design, in the award of contracts, during the construction process, and post construction stage including maintenance of completed projects. Many features of the building industry present enormous opportunities for corruption to flourish. First is the size of building projects where contracts tend to be huge in monetary value and yet the companies with financial and technical capability to implement them are few (Shakantu 2003). Secondly, the uniqueness of many projects makes costs difficult to compare, which in turn makes it easier to inflate costs or hide bribes (Robb 1996, Zhuwakinyu 2003). Furthermore, there is the issue of the concealed nature of a large proportion of building works. For example, foundations, which cost between $10 \%$ and $15 \%$ (depending on foundation types) of the total building cost, are concealed beneath the ground; structural steel works are concealed within concrete, electrical and mechanical fittings are concealed within walls. This makes it costly or difficult to verify bad workmanship or inferior materials after the work is completed. And, where the government is the client, unnecessary bureaucratic bottlenecks (usually associated with government projects) and numerous permits for private projects are subject to abuse by government officials.

Following the growing consensus that corruption and other unethical practices are endemic in the building industry, coupled with scarce empirical academic research on professional ethics in the Nigerian building industry, there is a need to examine professionals' ethical ideologies with a view to understanding their ethical behaviour in professional practice. 


\section{Ethical Ideologies and Decision Making}

Ethical ideologies can be explained as a set of beliefs, values and attitudes, which may influence an individual's judgment and decision-making when faced with difficult situations and ethical dilemmas. Henle et al. (2005: 219) defined ethical ideology as "a system of ethics used to make moral judgment, which offers guidelines for judging and resolving behaviour that may be ethically questionable". Perhaps, the significance of ethical ideology as suggested by Henle et al. (2005) is that ethical ideology may be an important mechanism through which organizations can determine which employees will engage in socially disapproved behaviour. Reducing, and ultimately, controlling the occurrence of these behaviours is paramount to organizations as the costs are high, both in immediate economic impact and in long-term effect on organizational culture and human resource management. Differences in moral philosophy or ethical ideology are contending with differences in ethical judgments (Schlenker and Forsyth 1977, Forsyth 1980, 1992).

It is well accepted that moral philosophy or ethical ideology influences an individual's reasoning about moral issues and consequent behaviour (Fritzsche and Becker 1984). Individuals often adopt a set of philosophical assumptions as a basis for making ethical decisions. Philosophy divides assumptions about ethics into two: the Teleological and the Deontological approaches. These two approaches differ in terms of the ways they understand what constitutes ethical behaviour (Johnson 2003).

The Teleological approach, also known as consequentialism, determines the moral worth of behaviour totally by the (anticipated) consequences. This suggests a cost benefit view, perhaps invoking the judgmental criterion of "the greatest good for the greatest number". Three examples of the Teleological approach to ethics are Egoism, Utilitarianism and Altruism. Egoism focuses on self-interest. This ethical principle is used as justification when something is done to further an individual's own welfare. Thus, egoism concerns pursuit of self-interest and so can be related to common business criteria (notably profit maximisation). The principle of Utilitarianism embodies the notion of operating in the public interest rather than for personal benefit. The principle extracted from this theory determines an action to be right if it maximises benefits over costs for all involved, everyone counted equal. The principle extracted from Altruism determines an action to be right if it maximises the benefits of some persons, even at the cost to oneself, i.e. that man has no right to exist for his own sake, that service to others is the only justification of his existence, and that self-sacrifice is his highest moral duty, virtue, and value.

The Deontological approach, stresses the methods or intention involved in a particular behaviour. According to a Deontological framework, actions are essentially right or wrong regardless of the consequences they produce. An ethical action might be deduced from a duty (pluralism) or a basic human right (contractarianism) but it never depends on its projected outcome. Duties and obligations have been classified under several categories including duties to God, duties to oneself, and duties to others, which include duties to family, social duties, and civic duties. Ethical theory dealing with rights generally can be summarised as providing a guide for the decision maker to insure respect for the right of individuals. The following five rights have been suggested by moral theorists (Cavanagh et al. 1981): the right to free consent, the right to privacy, the right to freedom of conscience, the right to free speech and the right to due process.

Schlenker and Forsyth (1977) suggest that individual variations in personal moral philosophies can be described most parsimoniously by taking into account the degree to which an individual is relativistic and/or idealistic. Relativism describes the extent to which individuals reject universal moral rules or principles. Idealism on the other hand, describes individual's attitudes toward the consequences of an action and the effect of the action on the welfare of others. Highly idealistic individuals believe in moral absolutes and rely on universal moral principles or laws to evaluate the ethics of an action (Forsyth 1992). To 
describe extremes, some individuals idealistically assume that desirable consequences can always be obtained with the 'right' action and those with less idealistic orientation admit that undesirable consequences will often be mixed in desirable ones (Forsyth 1980).

In an effort to understand ethical conduct, Forsyth (1980) argued that the belief in maximising positive consequences can be represented in terms of a range (i.e., high vs. low acceptance of harm). Similarly, the acceptance of moral absolute could be perceived not as binary but as a continuum (i.e. high vs. low acceptance of absolutes). Forsyth employed the term idealism to represent a moral dimension related to the acceptance of harm (i.e. concern for others). Relativism was chosen as the moral dimension that identifies the degree of acceptance of moral absolutes. The $2 \times 2$ matrix of these two dimensions yield Forsyth's ethical taxonomy. Forsyth's taxonomy indicates that individuals may adopt one of four different approaches to making ethical judgments: situationism, absolutism, subjectivism and exceptionism. The situationists distrust the absolute moral principles and argue that each situation needs to be examined individually. The subjectivists on the other hand are high on relativism and low on idealism. They reject the idea of universal ethical principles and believe moral decisions are based on individualistic judgments and negative consequences do not necessarily make any action immoral.

On the non-relativistic or low relativistic side of the typology are absolutists and exceptionists. Absolutists tend to reject the use of consequences of an action as basis for moral evaluation and appeal to natural law or rationality to determine ethical judgments. Exceptionists on the other hand are low on relativism and low on idealism. They endorse the statement that morality of an action depends upon the consequences produced by it.

Inclusion in one of these groups is determined by whether a person espouses idealistic or non-idealistic values and believes moral rules are universal or relative (Forsyth 1980). It also suggests that relativists and idealists both can be either low or high in relativism and idealism.

Each one of the four approaches draws from a specific school of thought in philosophy of ethics. For example, the high relativism groups - the situationists and subjectivists-are individuals who endorse an ideology related to ethical scepticism (Forsyth 1980). Skeptics believe that morality can be viewed in different ways and all kinds of scepticism criticize proponents of specific ethical principles. Ethical egoism, for example, is a sceptical ethical philosophy in which a pragmatic approach is taken to evaluate actions. On the nonrelativistic/low relativistic side of the typology are absolutists and exceptionists. Absolutists tend to agree with statements that are consistent with a general approach to moral philosophy known as deontology (Forsyth 1980). A deontological system is based on the rules and principles which govern decisions (Hartman 1998). This ethical philosophy rejects the use of consequences of an action as the basis for moral evaluation and appeals to natural law or rationality to determine ethical judgments. The statements endorsed by exceptionists are more compatible with teleological ethical philosophy (Forsyth 1980). The teleological approach proposes that the morality of an action depends upon the consequences produced by it. One is ethically bound to act in a way that produces good for the greatest number which is best represented by the utilitarian concept of greatest good for the greatest number.

Figure 1 indicates Forsyth's taxonomy of ethical ideologies along with a brief description of the characteristics of individuals within each category. This conceptualization is based on philosophical theories of deontology, teleology and ethical scepticism (Schlenker and Forsyth 1977, Forsyth 1980). 


\begin{tabular}{|c|c|c|c|}
\hline & \multicolumn{2}{|c|}{ Relativism } \\
\hline & & High relativism & Low relativism \\
\hline \multirow{2}{*}{ 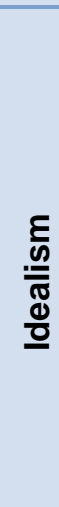 } & 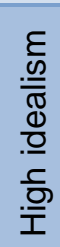 & $\begin{array}{l}\text { Situationist } \\
\text { Rejects moral rules; advocates } \\
\text { individualistic analysis of each act in } \\
\text { each situation; relativistic Justice } \\
\text { concepts }\end{array}$ & $\begin{array}{l}\text { Absolutist } \\
\text { Assumes that the best possible outcomes } \\
\text { can always be achieved by } \\
\text { Following universal moral rules Norm, } \\
\text { Rights \& Rule concepts }\end{array}$ \\
\hline & 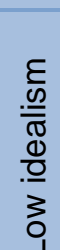 & $\begin{array}{l}\text { Subjectivist } \\
\text { Appraisals based on personal values } \\
\text { and perspective rather than universal } \\
\text { moral principles; relativistic } \\
\text { Egoism concepts }\end{array}$ & $\begin{array}{l}\text { Exceptionist } \\
\text { Moral absolutes guide judgments but } \\
\text { pragmatically open to exceptions to these } \\
\text { standards; utilitarian } \\
\text { Categorical imperative \& utilitarian } \\
\text { concepts }\end{array}$ \\
\hline
\end{tabular}

Figure 1 Taxonomy of ethical ideologies

Source: modified from Forsyth (1980: 176)

The connection between building industry professionals' ethical behaviour and ethical ideology is significant in understanding the value held by professionals as well as providing a basis for altering behaviour in a more ethical direction in the best interest of society where the situation warrants. Similar studies have been conducted among marketing managers in America (Fritzsche and Becker 1984), managers in large manufacturing enterprises in India (Monga 2001), psychologists and physicians in Canada (Hadjistavropoulos et al. 2003), senior Australian managers (Fernando et al. 2007) and Portuguese chartered accountants (Marques and Pereira 2009). The aim of this research is to extend studies based on Forsyth's taxonomy of ethical ideologies to professionals in the building industry. This is in view of the negative image of the industry globally and the international community perception of Nigerian especially as regards corruption and other unethical conducts.

\section{Research Method}

The research area comprised four major Nigerian cities: Abuja, Kano, Lagos and PortHarcourt. These cities were selected because they are major cities located in four of six geopolitical zones in Nigeria having the highest number of registered construction contracting and consultancy organisations with the various professional institutions. Furthermore, these cities have high professional concentrations because of the high volume of construction workload and activities and have experienced high incidence of building collapse in the last decade.

The target population for this study comprised core building industry professionals involved in the procurement of building projects. These include Architects, Builders/Construction Managers, Structural Engineers, Quantity Surveyors, and Services Engineers (Electrical and Mechanical). Other built -environment professionals such as estate surveyors and town planners were excluded because of the insignificant role they play in the procurement process of building projects. The population sample was drawn from professionals in 18 client organisations, 55 consulting and 35 contracting organisations in the building industry, making 108 organisations.

Due to unavailability of a single data base for all construction professionals in the different organizations (consultancy, contracting and client organisations) in the research areas from which an accurate sampling frame could be developed, the list of registered consulting firms in the respective professional institutions were used. These include: Nigerian Institute of Architects (NIA), Nigerian Institute of Building (NIOB), Nigerian Institute of Quantity Surveyors (NIQS); and Nigerian Institution of Structural Engineers (NISE). Data relating to 
contractors were sourced from the lists of contractors accredited by the Nigerian Institute of Building (NIOB) as published in the register of contractors (2003).

A simple random sampling technique was adopted for consultancy and contracting organisations. Consultancy firms were sampled based on a registration list of consultancy firms obtained from the professional institutions of the sampled professional groups. The construction firms were sampled from the list of contracting firms accredited and registered with the Nigerian Institute of Building. The population was stratified according to their operational base within the research areas and a simple random sampling of the population within each city in the research area was carried out using tables of random numbers. A snowball sampling technique was adopted for professionals in client's organisations because of the unavailability of a sample frame from which an accurate sample size could be drawn.

Forsyth's (1980) Ethics Position Questionnaire (EPQ), which contains 20 attitude statements was used to measure ethical ideologies and moral philosophy held by individuals. This instrument was used because it has demonstrated acceptable level of internal consistency (Schelenka and Forsyth 1977, Forsyth 1980). It is valid and not reflective of social desirability bias (Barnett, Bass, Brown, and Hebert, 1998). The EPQ has also been used in a variety of studies, such as Singhapakdi et al. (1994), Barnett et al. (1994), Rawwas and Patzer (1995), Bass et al. (1999) and recently Fernando, et al. (2008) and Marques and Pereira (2009). There is at present no acceptable alternative instrument for measuring the level of idealism and relativism other than the EPQ. The first ten questions of the EPQ form a subscale to measure idealism and the next ten, measure relativism.

The response format originally designed by Forsyth (1980) was altered in several previous studies. Van Kenhove et al. (2001) uses 5-point Likert scale (Cronbach's coefficient was .84 for idealism scale and .77 for the relativism scale). Redfern and Crawford (2004) reported reliability estimate of .86 and .70 for idealism and relativism respectively. Fernando et al. (2008) uses 4- point Likert scale. No reliability estimate was reported in Fernando et a/s study, however, seven out of ten idealism items and eight out of ten relativism items were used in the study. Marques and Pereira (2009) uses 7-point Likert scale (Cronbach coefficient was .80 and .87 for idealism and relativism respectively. Wilson (2003) reported Cronbach's coefficient of .79 and .68 for idealism and relativism respectively for a 7-point Likert scale.

In this study, instead of the 9-point Likert scale used in Forsyth's (1980) study, a 4-point Likert scale was used for measurement, with 4 indicating "strongly agree" and 1 indicating "strongly disagree". The choice of a 4-point Likert scale used in this study (without 'neutral' response) is for simplicity in rating respondents' degree of agreement and is based on the conviction that a neutral answer really does not indicate an ethical position. The idealism scale for this sample appear to be internally inconsistent, having Cronbach's alpha of .60 while the relativism scale had a Cronbach's alpha of .82 .

Principal-component factoring and orthogonal varimax rotation yielded 13 factors (all ten factors from idealism scale and three factors from relativism scale) that accounted for $69.85 \%$ of the total variance and had eigenvalues $\geq 1.0$. Questions $16-20$ on the relativism scale did not load on the rotated component matrix (suppressed absolute value <.4) and removing items with low extraction communalities did not improve the reliability estimate. It appears that the decision to simplify the scale format by reducing them to four affected the reliability of the idealism sub-scale.

Idealism and relativism scores of each respondent were assessed by calculating the mean of the answers to the first 10 items and the last 10 items, respectively. Higher scores on both idealism and relativism dimensions indicate higher levels of idealism and relativism. 
To classify the respondents into one of the four ethical ideologies, idealism and relativism scores were used. This was done by using the median scores of idealism and relativism as cut-off points. The median scores for both idealism and relativism were 20 . The maximum score an individual can attain for either idealism or relativism subscale is 40 . A scale of between 28 and 40, i.e. $70 \%$ and above is considered high for both idealism and relativism while any score below 20 , i.e. $50 \%$ is considered low for both subscales. Respondents that scored high on idealism and on relativism were classified as situationists $(n=136)$. Respondents that scored high on idealism and low on relativism were classified as absolutists $(n=40)$. Table 1 presents the number of questionnaires administered and those returned.

\begin{tabular}{|l|c|c|c|c|c|}
\hline \multirow{2}{*}{$\begin{array}{c}\text { Construction } \\
\text { organisation }\end{array}$} & $\begin{array}{c}\text { Population in } \\
\text { research } \\
\text { area }\end{array}$ & \multicolumn{4}{|c|}{ Questionnaire responses } \\
\cline { 5 - 6 } & & $\begin{array}{c}\text { Total } \\
\text { administered }\end{array}$ & Returned & Unreturned & $\begin{array}{c}\text { Percentage of } \\
\text { population } \\
\text { covered }\end{array}$ \\
\hline Client & $18^{*}$ & 200 & 102 & 98 & 100 \\
\hline Consultancy & 198 & 100 & 55 & 45 & 27 \\
\hline Contracting & 162 & 50 & 35 & 15 & 22 \\
\hline Total & 378 & 350 & 192 & 158 & \\
\hline
\end{tabular}

Table 1 Population and sample size of respondents in the three organisational groups

Notes: "represents the population of client organisations and other figures represent population of professionals.

The variation in the number of administered questionnaire in the respective organisations is based on the population of respondents in consultancy and contracting organisations in the research areas. One hundred and ninety two questionnaires were received. This represents a response rate of $55 \%$.

\section{Hypothesis}

The hypothesis postulated for the study is:

$\mathrm{H}_{0}$ : There is no significant difference in ethical ideology of professional groups in the building industry

$\mathrm{H}_{1}$ : There is a significant difference in ethical ideology of professional groups in the building industry

\section{Results and Discussion}

From the biographical information of the respondents presented in Table 2, the male respondents constitute $86 \%$ of the entire population while the female make up the remaining $14 \%$. This agrees with the finding that construction is a male dominated profession. Those between 21 and 30 years old are 13\%, those between 31 and 40 years old are $34 \%$, those between 41 and 50 years old are $42 \%$ and those above 50 years old are $11 \%$. This implies that majority of the respondents (76\%) are between 31 and 50 years old. In terms of educational qualification of the respondents, three percent of the respondents are Ordinary National Diploma (OND) holders, 20\% are Higher National Diploma (HND) holders, $26 \%$ are bachelors' degree holders, 39\% are Masters degree holders and two percent are doctorate degree holders. The implication is that majority of the respondents have adequate educational background. In terms of professionals' work experience in the industry, $10 \%$ have less than five years experience, $23 \%$ have between 6 and 10 years experience, 33\% have $11-20$ years experience, $27 \%$ have $31-40$ years experience while a few have above 40 years experience in the industry. This suggests that respondents have adequate experience, 
hence information provided by the respondents pertaining to ethical issues in the industry could be relied on.

\begin{tabular}{|c|c|c|}
\hline & & Percentage \\
\hline Gender & $\begin{array}{l}\text { Male } \\
\text { Female }\end{array}$ & $\begin{array}{l}86 \\
14\end{array}$ \\
\hline Age & $\begin{array}{l}21-30 \text { years } \\
31-40 \text { years } \\
41-50 \text { years } \\
>50 \text { years }\end{array}$ & $\begin{array}{l}13 \\
34 \\
42 \\
11\end{array}$ \\
\hline $\begin{array}{l}\text { Educational } \\
\text { qualification }\end{array}$ & $\begin{array}{l}\text { OND } \\
\text { HND } \\
\text { Bachelors } \\
\text { PGD } \\
\text { Masters } \\
\text { Doctorate }\end{array}$ & $\begin{array}{c}3 \\
20 \\
26 \\
10 \\
39 \\
2\end{array}$ \\
\hline $\begin{array}{l}\text { Organization } \\
\text { type }\end{array}$ & $\begin{array}{l}\text { Client organisation } \\
\text { Consultancy organisation } \\
\text { Contractor organisation }\end{array}$ & $\begin{array}{l}53 \\
27 \\
18\end{array}$ \\
\hline $\begin{array}{l}\text { Managerial } \\
\text { position }\end{array}$ & $\begin{array}{l}\text { Top } \\
\text { Middle } \\
\text { Junior }\end{array}$ & $\begin{array}{c}44 \\
54 \\
2\end{array}$ \\
\hline $\begin{array}{l}\text { Industry } \\
\text { experience }\end{array}$ & $\begin{array}{l}\text { Less than } 5 \text { years } \\
6-10 \text { years } \\
11-20 \text { years } \\
21-30 \text { years } \\
31-40 \text { years } \\
\text { Over } 40 \text { years }\end{array}$ & $\begin{array}{l}10 \\
23 \\
33 \\
27 \\
05 \\
01\end{array}$ \\
\hline $\begin{array}{l}\text { Professional } \\
\text { affiliation }\end{array}$ & $\begin{array}{l}\text { Architecture } \\
\text { Building/construction } \\
\text { management } \\
\text { Civil/structural. Engineering } \\
\text { Quantity surveying } \\
\text { Building Services } \\
\text { Engineering }\end{array}$ & $\begin{array}{c}22 \\
25 \\
24 \\
21 \\
7\end{array}$ \\
\hline $\begin{array}{l}\text { Professional } \\
\text { membership } \\
\text { status }\end{array}$ & $\begin{array}{l}\text { Non-member } \\
\text { Student } \\
\text { Graduate } \\
\text { Corporate } \\
\text { Fellow }\end{array}$ & $\begin{array}{c}6 \\
4 \\
31 \\
54 \\
5\end{array}$ \\
\hline
\end{tabular}

Table 2 Profile of study sample

As regards the professional affiliation of respondents, $22 \%$ are architects, $25 \%$ are builders/ construction managers, $24 \%$ are structural engineers, $22 \%$ are quantity surveyors and seven percent are building services engineers. Fifty three percent of the respondents are in client organisations, $29 \%$ are in consultancy organisations while the remaining $18 \%$ are in contractors' organisations. In terms of managerial positions of the respondents, $44 \%$ are in top managerial positions, $54 \%$ are in middle managerial positions and an insignificant proportion (2\%) are in junior managerial positions. This implies that the majority of the respondents are involved in decision making with respect to project procurement. In terms of professional membership status, $31 \%$ are graduate members of their respective professional institutions while 54\% are corporate members and few $(5 \%)$ are fellows of their respective professional institutes. This means that an overwhelming majority of the surveyed respondents (85\%)

belong to their professional associations, which have codes of conduct that provide guidelines for business and professional behaviour and ethics.

\section{Professional's Ethical Ideology}

There is much empirical support for the notion that an individual's ethical belief, values or ideology influences their approach to ethical judgement and consequent behaviour. Table 3 presents the ethical position of all respondents according to Forsyth's taxonomy.

The result indicates that overwhelming majority of the respondents $(77 \%)$ were found to be situationists while only $23 \%$ were absolutists. Situationists reason that people's situations, rather than their characters, are the explanatory powerful factors in determining why different people behave differently. A situationist is an individual who endorses an ideology related to moral philosophy known as ethical scepticism. A sceptical point of view recognises that there are many different ways to look at morality of an action. According to Fletcher 1966 (in

Ameh, J.O and Odusami, K.T. (2010) 'Nigerian building professionals' ethical ideology and perceived ethical judgement', Australasian Journal of Construction Economics and Building, 10 (3) 1-13 
Forsyth 1980), an idealistic sceptic focuses on "a contextual appropriateness - not the 'good' or the 'right' but the 'fitting' with all actions based on 'agape' or love of others".

The absolutists, on the other hand, agree with statements that are consistent with a general approach to moral philosophy known as deontology. Moral absolutists are of the belief that all of morality consists in inflexible axiomatic principles, which must be followed exactly. This ethical perspective implies that any professionals' proposed course of action (which adversely affects the project quality, cost and time) that is not widely acceptable or that cannot be seen as a universal law that applies to all professionals in all situations at all times, is unethical.

\begin{tabular}{|c|c|c|c|c|c|c|c|c|c|}
\hline \multirow{3}{*}{$\begin{array}{c}\text { Profession } \\
\text { Architect }\end{array}$} & \multirow{3}{*}{$\begin{array}{l}\mathrm{N} \\
39\end{array}$} & \multicolumn{2}{|c|}{ IDEALISM } & \multicolumn{2}{|c|}{ RELATIVISM } & \multicolumn{4}{|c|}{ ETHICAL POSITION } \\
\hline & & \multicolumn{2}{|c|}{$\begin{array}{l}\text { High Low } \\
\text { Percentage }\end{array}$} & \multicolumn{2}{|c|}{$\begin{array}{l}\text { High Low } \\
\text { percentage }\end{array}$} & \multicolumn{2}{|c|}{$\begin{array}{c}\text { SITUATIONIST } \\
\mathrm{N} \%\end{array}$} & \multicolumn{2}{|c|}{$\begin{array}{c}\text { ABSOLUTIST } \\
\mathrm{N} \%\end{array}$} \\
\hline & & 100 & 0 & 74 & 26 & 2 & 74 & 10 & 26 \\
\hline $\begin{array}{c}\text { Builder/ } \\
\text { Construction } \\
\text { Manager }\end{array}$ & 42 & 100 & 0 & 79 & 21 & 3 & 79 & 9 & 21 \\
\hline Quantity Surveyor & 38 & 100 & 0 & 82 & 18 & 3 & 82 & 7 & 18 \\
\hline $\begin{array}{l}\text { Structural } \\
\text { Engineers }\end{array}$ & 44 & 100 & 0 & 73 & 27 & 32 & 73 & 12 & 27 \\
\hline Services engineers & 13 & 100 & 0 & 100 & 0 & 11 & 85 & 2 & 15 \\
\hline Total & 176 & 100 & 0 & 77 & 23 & 136 & 77 & 40 & 23 \\
\hline
\end{tabular}

Table 3 Ethical ideology of professionals involved in the procurement of building projects

A number of other studies have used Forsyth's (1980) EPQ. In Asia, Singhapakdi et al. found Thai managers to be high in moral idealism. Rawwas (1996) applied EPQ to Australian consumers. He found that Australian consumers are mostly situationists $(62 \%)$, $18 \%$ are absolutists, $10 \%$ are exceptionist and $10 \%$ are subjectivists. Davis, et al. (1998) found that Indonesian MBA students scored high on relativism, while US respondents scored high on idealism. Lee and Sirgy (1999) found Korean managers were higher on idealism than US managers; relativism was not significantly different between the two groups. Redfern (2005) found Chinese managers in highly industrialised regions to be high on both the idealism and relativism dimensions.

A number of factors may influence the ethical decision making process. According to Hunt and Vitell (1986), the individual ethical perception of the situation is influenced by a sum of cultural, organisational and industrial environment along with personal experience. For Trevino (1986), in organisational context both the individual and situational factors affect the decision making. Trevino and Nelson (1999) emphasised that ethical conduct depends to a large extent on external factors such as the expectations of the authority figures, one's position in the organisational hierarchy, what the colleagues are doing, the reward system and the role that an individual is asked to play.

Situational factors that can exert tremendous negative influence on building industry professionals' ethical behaviour in Nigeria are many. These include: delay in paying professional fees as at when due by public and private clients, requests for a bribe from professionals by officials in public service before processing professionals' fees for payment, and or public office holders corruptly enriching themselves through inflated contract figures. 
These negative tendencies may be a justification for building professionals to engage in unethical practices (Ameh and Odusami 2010). With respect to ethical impropriety in the procurement of building projects and its adverse effect on the society, economy and the environment, absolutist ethical ideology is preferable to situationist ethics. This is because, irrespective of the situational variables and or benefits derived by the agent performing the act, rules regarding honesty, probity and trustworthiness ought to be respected and upheld.

\section{Test of Hypothesis}

The result of descriptive statistics (Table 4) and one way analysis of variance (ANOVA) is presented in Table 5. The data for Building Services was excluded from the ANOVA analysis because of their small sample size. The final analysis indicates that there is no statistically significant difference $(p<.05)$ in the ethical ideology of different categories of building professionals. Hence the null hypothesis which states that "There is no significant difference in ethical ideology of professional groups in the building industry" is accepted. This implies that similar moral philosophy influences the ethical behaviour of professionals in the Nigerian building industry.

\begin{tabular}{|c|c|c|c|c|}
\hline Building profession & N & Mean & Std. Deviation & Std. Error \\
\hline Architecture & 39 & 1.51 & 0.885 & 0.142 \\
\hline Building & 42 & 1.43 & 0.831 & 0.128 \\
\hline Structural Engineering & 44 & 1.55 & 0.901 & 0.136 \\
\hline Quantity Surveying & 38 & 1.31 & 0.741 & 0.120 \\
\hline Total & $\mathbf{1 6 3}$ & $\mathbf{1 . 4 5}$ & $\mathbf{0 . 8 4 1}$ & $\mathbf{0 . 0 6 6}$ \\
\hline
\end{tabular}

Table 4 Descriptive statistics of building professional groups ethical ideology

\begin{tabular}{|c|c|c|c|c|c|c|c|}
\hline & $\begin{array}{l}\text { Sum of } \\
\text { Squares }\end{array}$ & DF & $\begin{array}{c}\text { Mean } \\
\text { Square }\end{array}$ & $\begin{array}{c}\text { F- } \\
\text { statistics }\end{array}$ & $\begin{array}{c}p- \\
\text { value }\end{array}$ & $\begin{array}{c}\text { Level of } \\
\text { Significance }\end{array}$ & Decision \\
\hline Between Groups & 1.298 & 3 & 0.433 & 0.607 & .611 & NS & $\begin{array}{c}\text { Accepted } \\
\mathrm{H}_{0}\end{array}$ \\
\hline Within Groups & 113.266 & 159 & 0.712 & & & & \\
\hline Total & 114.563 & 162 & & & & & \\
\hline
\end{tabular}

Table 5 ANOVA for professionals' ethical ideology

Notes: NS= Not significant at $p<.05$

\section{Conclusion}

An individual ethical ideology provides guidelines for evaluating ethically questionable behaviours and ultimately deciding to refrain or engage in them. Given a well documented perception of Nigerians as being corrupt, and since Nigerian building industry professionals may not be immune from the perceived national trend in ethical erosion, it is relevant to investigate the ethical ideology held by Nigerian building industry professionals. The results indicate that professionals in the Nigerian building industry are high in both idealism and relativism. Idealism and relativism have been extensively used in the business ethics literature. Idealism and relativism have been shown to influence the perception of ethical problems (Hunt and Vitell 1986); the perceived importance of ethics and social responsibility (Singhapakdi et al. 1995); ethical sensitivity (Sparks and Hunt 1998); ethical intention and perceived moral intensity (Singhapakdi et al. 1999) and organizational deviance (Henle et al. 2005). According to Forsyth's (1980) taxonomy, Nigerian building industry professionals' dominant ethical ideology can be regarded as situationism. Situationism implies that people are much more susceptible to being corrupted than one might expect, which in turn means 
that in order for their good behaviour to remain stable and consistent, they must also be put in the proper kind of situations as well. Judging by the characteristics of situationists, the study therefore concludes that the behaviour of building industry professionals in professional practice could possibly be unethical.

The identification of situationism as the dominant ethical ideology of the Nigerian building industry professionals would be of interest to policy makers because it is a bold step and necessary benchmark for resolving ethical issues in the construction industry. This is because each individual will make ethical decisions based on the actual situation. The large potential for corrupt practice in the construction industry, such as public office holders corruptly enriching themselves through inflated contract figures, the influence of peers, organisational culture, and an unstable political climate, provides a set of explanatorily powerful factors influencing professional conduct. These findings also form the basis for intra-professional ethical comparison.

To curb professionals' ethical impropriety in the procurement of building projects in Nigeria, it is therefore recommended as follows:

1. Since majority of the Nigerian building industry professionals are situationists, such factors that will encourage unethical practices should be avoided. This may necessitate national ethical re-birth and massive enlightenment on ethical codes.

2. Since knowledge improves the chances for ethical behaviour over ignorance, the professional institutes should organise periodic training sessions as part of Continuous Professional Development (CPD). Issues to be discussed at such meetings should include:

i. content(s) analysis of professional codes of conduct

ii. case studies and scenarios on ethical improprieties

iii. emerging ethical issues of global and national significance.

This can result in the attainment of a national ethical mind-set as well as value reorientation of all professionals that will ensure that building industry professionals react "automatically" and intuitively to being virtuous and upholding high ethical standards.

\section{Study Limitation}

The value of Cronbach's alpha coefficient for idealism scale was low in comparison to the values reported in other studies. This may be because the Likert scale response format used in this study is below 5. Another limitation in this study is the small sample of building services respondents.

\section{Acknowledgement}

The researchers gratefully acknowledge the support of the University of Lagos Central Research Committee (CRC) for its grant (CRC/2004/27) which facilitated this research.

\section{References}

Ameh, O. J. and Odusami, K. T. (2010) 'Professionals' ambivalence towards ethics in the Nigerian construction industry', Journal of Professional Issue in Engineering Education and Practice, 136(1), 9-16

Barnett, T., Bass, K., and Brown, G. (1994) 'Ethical ideology and ethical judgment regarding ethical issues in business', Journal of Business Ethics, 13(6), 469-480

Barnett, T., Bass, K., Brown, G. and Herbert, F. J. (1998) 'Ethical ideology and ethical judgement of marketing professionals', Journal of Business Ethics, 17(7), 15-723 
Bass, K., Barbett, T. and Brown, G. (1999) 'Individual difference variables, ethical judgments and ethical behaviour intentions', Business Ethics Quarterly, 9(2), 183 - 205

Cavenagh, G. F., Moberg, D. J., and Valesquez, M. (1981) The ethics of organisational politics, Academy of Management Review, 6, 363-374

Davis, M. A., Johnson, N. B. and Ohmer, D. G. (1998) 'Issue contingent effects on ethical decision making: a cross cultural comparison', Journal of Business Ethics, 17, 373-389

Fernando, M., Dharinage, S. C. and Almeida, S. (2008) 'Ethical ideologies of senior Australian managers: an empirical study', Journal of Business Ethics, 82,145-155

Forsyth, D. R. (1980) 'A taxonomy of ethical ideologies', Journal of Personality and Social Psychology, 39(1), 175-184

Forsyth, D. R. (1992) 'Judging the morality of business practices: The influence of personal moral philosophies', Journal of Business Ethics, 11(5-6), 461-470

Fritzsche, D. J. and Becker, H. (1984) 'Linking management behaviour to ethical philosophyan empirical investigation', Academy of Management Journal, 27(1), 166-175

Hadjistavropoulos, T., Malloy, D. C., Sharpe, D. and Fuchs-Lacelle, S. (2003) 'The ethical ideologies of psychologists and physicians: a preliminary comparison', Ethics and Behaviour, 13(1), 97-104

Hartman, L. P. (1998) Perspectives in business ethics. Singapore: McGraw-Hill

Henle, C., Giacalone, R and Jurkieweiz, C. (2005) 'The role of ethical ideology in workplace deviance', Journal of Business Ethics, 56, 219-230

Hunt, S. D. and S. Vitell (1986) 'A General Theory of Marketing Ethics', Journal of Macromarketing , 8, 5-16

Johnson, R. N. (2003) 'An overview of ethical theory', Available [on-line] http://www.nwmissouri.edu/rfield/274, accessed 24/06/03

Lee, D. J. and Sirgy, M. J. (1999) 'The effect of ethical ideology and ethnocentrism on quality of life orientation in international marketing: a cross cultural comparison', Journal of Business Ethics, 18, 73-89

Marques, P. A. and Pereira, J. A. (2009) 'Ethical ideology and ethical judgments in the Portuguese accounting profession', Journal of Business Ethics, 86, 227-242

Monga, M. (2001) 'Ethics and ethical ideologies: an empirical study of managers in North Indian large manufacturing enterprises', Proceedings of Australian association of professional and applied ethics, Adelaide, September

Rawwas, M.Y.A and Patzer, G.L. (1995) 'Consumer ethics in cross-cultural settings entrepreneurial implications', European Journal of Marketing, 29(7), 62-78

Redfern, K. (2005) 'The influence of industrialisation on ethical ideology of managers in the people's republic of china', Cross Cultural Management, 12(2), 38-50

Robb, D. J. (1996) 'Ethics in project management: issues, practice, and motives'. Second Annual Conference of the Project Management Institute, New Zealand chapter conference, Auckland, Nov. 14 - 15, 1454-1457

Schlanker, B. R. and Forsyth, D. R. (1977) 'On the ethics of psychological research', Journal of Experimental Social Psychology, 13, 369-396

Shakantu, W. M. W. (2003) 'Corruption in the construction industry: forms, susceptibility and possible solutions', CIDB $1^{\text {st }}$ Postgraduate conference, Port Elizabeth, South Africa. 274283. Also available [on-line] www.cidb.org.za/CIDB. accessed 16th February, 2004

Singhapadi, A., Vitell, S. J. and Leelakulthanit, O. (1994) 'A cross-cultural study of ethical ideology, ethical perceptions and judgments - a comparison of American and Thai marketers', International Marketing Review, 11(6), 66 - 78 
Singhapakdi, A., Kraft, K. L., Vitell, S. J. and Rallapalli, K. C. (1995) 'The perceived importance of ethics and social responsibility on organizational effectiveness: a survey of marketers', Journal of Academy of Marketing Science, 23(1), 49-56

Singhapakdi, A., Vitell, S. J. and Franke, G. R. (1999) 'Antecedents, consequences, and mediating effects of perceived moral intensity and personal moral philosophies', Journal of the Academy of Marketing Science, 27(1), 19-35

Sparks, J. R. and Hunt, S. D. (1998) 'Marketing researcher ethical sensitivity: conceptualization, measurement, and exploratory investigation', Journal of Marketing 62(2), 92-109

Trevino, L. K. (1986) 'Ethical decision making in organizations: A person-situation interactionist model'. Academy of Management Review, 11(3), 601-617

Trevino, L. K. and Nelson, K. A. (1999) Managing business ethics-straight talk about how to do it, USA, John Wiley and Sons

Wilson, M. S. (2003) 'Social dominance and ethical ideology: The end justifies the means?' The Journal of Social Psychology, 143(5), 549-558

Zhuwakinyu, M. (2003) 'Corruption busting', Engineering news, January 24/2003. Available (on-line) www.odiusdebts.org, cited 05/08/2003 


\section{Appendix}

\begin{tabular}{|c|c|c|c|c|c|}
\hline S/No & General statements & $\begin{array}{l}\text { Strongly } \\
\text { agree } \\
\text { (4) }\end{array}$ & $\begin{array}{l}\text { Agree } \\
(3)\end{array}$ & $\begin{array}{l}\text { Disagree } \\
\quad(2)\end{array}$ & $\begin{array}{l}\text { Strongly } \\
\text { Disagree } \\
\text { (1) }\end{array}$ \\
\hline 1 & $\begin{array}{l}\text { A person should make certain that his/her actions never intentionally harm another even to a small } \\
\text { degree }\end{array}$ & & & & \\
\hline 2 & Risks to another should never be tolerated, irrespective of how small the risks might be & & & & \\
\hline 3 & The existence of potential harm to others is always wrong, irrespective of the benefits to be gained & & & & \\
\hline 4 & One should never psychologically or physically harm another person & & & & \\
\hline 5 & $\begin{array}{l}\text { One should not perform an action which might in any way threaten the dignity and welfare of another } \\
\text { individual }\end{array}$ & & & & \\
\hline 6 & If an action could harm an innocent person, then it should not be done & & & & \\
\hline 7 & $\begin{array}{l}\text { Deciding whether or not to perform an act by balancing the positive consequences of the act against the } \\
\text { negative consequences of the act is immoral }\end{array}$ & & & & \\
\hline 8 & The dignity and welfare of people should be the most important concern in any society & & & & \\
\hline 9 & It is never necessary to sacrifice the welfare of others & & & & \\
\hline 10 & Moral actions are those which closely match ideals of the most perfect action & & & & \\
\hline 11 & There are no ethical principles that are so important that they should be a part of any code of ethics & & & & \\
\hline 12 & What is ethical varies from one situation and society to another & & & & \\
\hline 13 & $\begin{array}{l}\text { Moral standards should be seen as being individualistic; what one person considers to be moral may be } \\
\text { judged to be immoral by another person }\end{array}$ & & & & \\
\hline 14 & Different types of morality cannot be compared as to "rightness" & & & & \\
\hline 15 & $\begin{array}{l}\text { Questions of what is ethical for everyone can never be resolved since what is moral or immoral is up to } \\
\text { the individual }\end{array}$ & & & & \\
\hline 16 & $\begin{array}{l}\text { Moral standards are simply personal rules which indicate how a person should behave and are not to } \\
\text { be applied in making judgments of others }\end{array}$ & & & & \\
\hline 17 & $\begin{array}{l}\text { Ethical considerations in interpersonal relations are so complex that individuals should be allowed to } \\
\text { formulate their own individual rules }\end{array}$ & & & & \\
\hline 18 & $\begin{array}{l}\text { Rigidly codifying an ethical position that prevents certain types of actions could stand in the way of } \\
\text { better human relations and adjustment }\end{array}$ & & & & \\
\hline 19 & $\begin{array}{l}\text { No rule concerning lying can be formulated; whether a lie is permissible or not permissible totally } \\
\text { depends upon the situation }\end{array}$ & & & & \\
\hline 20 & Whether a lie is judged to be moral or immoral depends upon the circumstances surrounding the action & & & & \\
\hline
\end{tabular}

Ameh, J.O and Odusami, K.T. (2010) 'Nigerian building professionals' ethical ideology and perceived ethical judgement', Australasian Journal of Construction Economics and Building, 10 (3) 1-13 